\title{
Characterization of Physical-Chemical and Structural Soil Attributes in the Semiarid Region of the Rio Grande do Norte State, Brazil
}

\author{
Thais Cristina de Souza Lopes ${ }^{1}$, Jeane Cruz Portela ${ }^{1}$, Stefeson Bezerra de Melo ${ }^{1}$, Valéria Nayara Silva de Oliveira ${ }^{1}$, \\ Rafael Oliveira Batista ${ }^{1}$, Joaquim Emanuel Fernandes Gondim ${ }^{2} \&$ Maria Elidayane da Cunha ${ }^{1}$ \\ ${ }^{1}$ Universidade Federal Rural do Semi-Árido, Mossoró, Brazil \\ ${ }^{2}$ Universidade Federal da Paraíba, Areia, Brazil \\ Correspondence: Jeane Cruz Portela, Universidade Federal Rural do Semi-Árido, Av. Francisco Mota, 572, Bairro \\ Costa e Silva, Mossoró, RN, Brazil. Tel: 55-840-996-933-669. E-mail: jeaneportela@ufersa.edu.br
}

Received: October 1, 2018

Accepted: December 1, 2018

Online Published: February 15, 2019

doi:10.5539/jas.v11n3p359

URL: https://doi.org/10.5539/jas.v11n3p359

\begin{abstract}
The study of the soil characterization and the relation of its attributes allows a systematic proposal of the local particularities, leading to adequate practices for maintenance and/or preservation of its productive capacity. In this sense, the aim of this study was to evaluate the influence of structural attributes in association with physical and chemical soil classes, using the multivariate statistical techniques to differentiate environments. The research was carried out in the Moacir Lucena Project, located in the municipality of Apodi, RN, Brazil. Three representative environments were chosen as follows: Profile 1 (P1)-Red-yellow Latosol-Area in recovery (1AR), P2-Haplic Cambisol-Lake Area, (2AL) and P3-Eutrophic Yellow Latosol-Cashew Tree Area (3AC). The soil samples were collected in the horizons of the studied areas. Ten (10) samples were collected per horizons in volumetric rings and in soil blocks (aggregate analysis), which resulted in triplicates in the laboratory. Structural, physical and chemical attributes were evaluated. The data were analyzed using multivariate statistical techniques, with correlation matrix, clustering analysis and factorial analysis performed by the extraction of the factors into principal components. The use of clustering analysis allowed the formation of four groups for soil classes and attributes; the inorganic fractions were determinant for environmental differentiation, where the sand was discriminant for the Red-yellow Latosol and the Eutrophic Yellow Latosol, and the clay and silt for the Haplic Cambisol. Higher similarity was observed in the transition horizons of the Latosols Class. The physical and structural attributes were determinant in the dissimilarity for the Haplic Cambisol, reflecting in physical restrictions to the plant growth. The factor analysis revealed that the variables particle density (Dp), $\mathrm{Ca}^{2+}, \mathrm{Mg}^{2+}$, sum of bases (SB) and cation exchange capacity (CEC) for factor 1 , followed by $\mathrm{pH}, \mathrm{P}, \mathrm{K}^{+}$, total Sand, Clay and soil density (Ds) for factor 2 are important soil attributes to distinguish the studied environments.
\end{abstract}

Keywords: caatinga, permanent preservation area, aggregates stability

\section{Introduction}

The Brazilian semiarid region presents variability in terms of lithology, climatic pattern, landscape and vegetation, resulting in peculiar characteristics of soil attributes (morphological, physical, chemical and mineralogical), and consequently its structural properties, being considered as one of the most important characteristic from the agricultural point of view, by indirectly influencing plant growth factors, since it controls air changes, water and heat, nutrient availability, and mechanical resistance to root development (Carvalho et al., 2017).

Since the soil structure is a dynamic and functional property, easily modified by anthropic action, its study is necessary as an aid to decision making, regarding the soil management practices and the choice of the agricultural crops, taking into consideration their potentialities and/or restrictions.

The activity of irrigated fruit growing became one of the prominent segments in the semiarid areas of the West of the Rio Grande Norte State, Brazil, in order to meet the demand for fruit exports to international markets and the increasing incorporation of new areas. It is important to take into consideration that the anthropic action in these environments by irrigated agriculture has led to soil degradation, reflecting in the reduction of productive capacity, since it is being used improperly and without observing the basic principles of soil conservation, not 
evaluating the local particularities, breaking the soil dynamics, avoiding the soil properly use, unbalancing the biodiversity and socially impacting the local farmers (Conceição et al., 2014).

It is important to notice that the studied areas are part of the Moacir Lucena Settlement Project and that the locals adopt natural resource conservation systems and are being invaded by agribusiness activities, which reflects negatively on the preservation of biodiversity and of every form of life. Thus, studies of the characterization of the structural attributes associated with physical and chemical resources are scarce in the region. In this perspective, it is necessary to study the environment characteristics, the use of soil attributes and their relations, with the aid of multivariate techniques as an efficient tool in distinguishing the most sensitive attributes.

Thus, the aim of the present study was to characterize the environments, through the study of the structural and chemical attributes in association with the inorganic fractions, aiming the separation of the environments through the most sensitive attributes, using the technique of multivariate analysis in soil classes in the Moacir Lucena settlement, at the Rio Grande do Norte State mesoregion, Brazil.

\section{Method}

The reseach was carried out at the Settlement Project Moacir Lucena at the Apodi municipality $\left(05^{\circ} 39^{\prime} 51^{\prime \prime}\right.$ S, $\left.37^{\circ} 47^{\prime} 56^{\prime \prime} \mathrm{W}\right)$, Rio Grande do Norte, Brazil, at the semiarid region and at the "apodi Chapada' microregion and the west mesoregion of the State. According to Koppen's classification, the region climate is BSwh', very hot and with natural vegetation of hyperxerophilic deciduous Caatinga (Alvares et al., 2013).

Thus, three representative environments of the Settlement were chosen as follows: Profile 1 (P1)-Yellow Red Latosol-Area under recovery (1AR), P2-Haplic Cambisol-Lake Area (2AL) and P3-Eutrophic Yellow Latosol-Cashew tree Area (3AC).

The 1AR refers to an area without planting, within the limits of the Permanent Preservation Area (APP) with approximately 2.5 hectares, where the settlers planted cotton, but has been in rest for 16 years to recover the native forest and soil. The 2AL is located within the boundaries of the APP area with an area around 4 to 5 hectares where, due to a difference of slope, present flooding in rainy periods. The 3CAJU area was previously used to plant cotton, beans and other crops and was inserted in the collective area, in 2007, with 20 hectares. Cashew trees were planted and at the beginning of winter beans are planted as an associate crop, with pruning and other traits on every year.

In each of the three studied environments, trench openings were carried out aiming at the description of the soil classes, collecting samples with deformed and not deformed structure in the soil horizons. The samples were placed in plastic bags and analyzed in the Laboratory of Soil, Water and Plant analysis of the Center of Agricultural Sciences of the Federal Rural Semiarid University (LASAP-CCA-UFERSA), following the methodology proposed by Teixeira et al. (2017).

Inorganic fractions were determined: texture (sand, silt and clay), as well as particle density (dp) and the consistency limits: Liquidity Limit (LL); Plasticity Limit (LP); Plasticity index (IP) and the soil structural atributes: density, macroporosity, microporosity, total porosity, volumetric humidity and aggregate stability (Average Weighted Diameter-DMP, Geometric Mean Diameter-DMG). The evaluated chemical attributes were: electrical conductivity (EC), $\mathrm{pH}$ in water, electrical conductivity of soil saturation extract (EC), exchangeable sodium percentage (PST), total organic carbon (TOC), phosphorus $(\mathrm{P})$, potassium $\left(\mathrm{K}^{+}\right)$, calcium $\left(\mathrm{Ca}^{2+}\right)$, magnesium $\left(\mathrm{Mg}^{2+}\right)$, cation exchange capacity (CEC) and base saturation (V).

The granulometry was obtained using chemical dispersant (sodium hexametaphosphate) and distilled water in 20 $\mathrm{g}$ of the air dried fine soil (TFSA), with slow mechanical agitation (Wagner $50 \mathrm{rpm}$ ) for 16 hours, the sand fraction $(2$ to $0.05 \mathrm{~mm})$ was quantified by sieving, the clay fraction $(<0.002 \mathrm{~mm})$ by sedimentation and the silt $(0.05$ to $0.002 \mathrm{~mm})$ by the difference between the total sand and clay fractions. The particle density analysis was carried out using the volumetric flask method, using the oven-dried fine soil (TFSE) at $105^{\circ} \mathrm{C}$ and ethyl alcohol.

Soil consistency tests were determined based on liquidity limits (LL) using the Casagrande apparatus. The plasticity limit (LP) was determined with three replicates and the representative sample was obtained from the central part of the soil shear in the metallic sphere of the equipment, being derived from the determination of the liquidity limit and forming a sphere, which was compressed on a plate to form a cylindrical rod with 3.0 to 4.0 $\mathrm{mm}$ in diameter, without breaking or flowing. The plasticity index (IP) was obtained by the difference between LL and LP. Gravimetric moisture was determined in the plasticity condition for the soil rods.

The intact samples were collected using the Uhland apparatus and rings with dimensions of $0.05 \mathrm{~m}$ in height and $0.05 \mathrm{~m}$ in diameter, with 10 (ten) samples per horizon in the respective profiles, for evaluation of the soil density attributes, macro and microporosity, total and determined porosity. Soil density was determined by the 
volumetric ring method, described by Forsythe (1975), with stablished volume and with the mean of the obtained values, being represented by the mass quotient of the soil solid particles by the total soil volume, and expressed in $\mathrm{kg} \mathrm{dm}^{-3}$.

For the analysis of macroporosity, microporosity and total porosity, the undeformed samples in the volumetric rings were saturated for 48 hours and weighed (to determine the total porosity). The method used to determine these properties was the "tension table" (Kiehl, 1979), at the $6 \mathrm{kPa}$ (microporosity) stress, with the total soil porosity (Pts) determined by measuring the samples saturation humidity, according to the equation: $\mathrm{Pt}=[(\mathrm{Msat}-$ $\mathrm{Ms}$ )/VT] $\times 100$, where Msat is the mass of the soil in the saturation condition; Ms is the mass of the dry soil and VT is the volume of the sample. The microporosity was determined by measuring the retained water content in the soil, for ' $h$ ' of $60 \mathrm{~cm}$ of water (approximately a pore radius of $25 \mu \mathrm{m}$ ). Soil macroporosity was determined by the difference between total porosity and soil microporosity.

For the aggregates study, block of the soil profiles were extracted in the respective horizons and in sieves with mesh opening of 4.00 and $2.00 \mathrm{~mm}$ (together). The wet sieving method was used with mesh sieves of 4.76; 2.00; $1.00 ; 0.50$ and 0.25 in the vertical oscillation apparatus (Kemper \& Rosenau, 1986). After separation of the aggregates obtained by shaking in water using the vertical oscillation apparatus (42 oscillations/minute), the samples were dried at $105^{\circ} \mathrm{C}$. After obtaining the dry mass, the sand content was discarded and the distribution of the aggregate size, percentage of aggregation and water-stable aggregates and DMP and DMG were obtained.

In order to perform the chemical analyzes, the following parameters were used: $\mathrm{pH}$ in water, EC in water, PST, TOC by the digestion of organic matter and macronutrients: exchangeable calcium $\left(\mathrm{Ca}^{2+}\right)$ and exchangeable magnesium $\left(\mathrm{Mg}^{2+}\right)$ with potassium chloride extractor, phosphorus $(\mathrm{P})$, sodium $\left(\mathrm{Na}^{+}\right)$and potassium $\left(\mathrm{K}^{+}\right)$, with the Mehlich extractor 1, being calculated the CEC, V and PST, evaluated according to the Manual of Recommendations for the use of correctives and fertilizers from Minas Gerais State, Brazil (Ribeiro \& Guimarães, 1999).

The data of the deformed structure attributes were expressed using four replications and submitted to statistical analysis using the multivariate analysis technique, as the main tool used to detect the most sensitive attributes in the distinction of soil environments under different uses, with the aid of the Statistica 7.0 Software (StatiSoft, 2004).

The analytical results were standardized by the Pearson's correlation matrix and submitted to multivariate techniques such as cluster analysis (AA), factorial analysis (FA) and principal component analysis (PCA).

Pearson's correlation analysis $(p \leq 0.05)$ was used for the 28 variables in order to guarantee the sufficient minimum correlations to justify their use in FA data matrix. For FA, factors with eigenvalues above 1 were extracted by principal components and the factorial axes were rotated by the Varimax method. For this study the value of 0.65 was established for significant factorial weights (Hair Jr. et al., 2009).

The cluster analysis (AA) was represented by the vertical dendogram of the distance matrix. The Euclidean distance was adopted as a measure of similarity and Ward's method for linking cases. In AA, the importance of each variable in the distinction of the environments is measured as a function of its smaller distance from the reference axis, the $\mathrm{x}$ or $\mathrm{y}$ axis, and the axis that contains the largest value of accumulated variance explains part of the causes of variation (Sá Paye et al., 2012).

Assigning the value 0.1 for the binding distance in the dendrogram for the environments and 2 for the attributes obtained from the cluster analysis, it was possible to identify four groups for both (Figure 1A and B).

In FA, factors with eigenvalues above 1.0 were extracted by the principal components, and the factorial axes were rotated by the Varimax method. The value of 0.65 for significant factor loads was established for this study (Hair Jr. et al., 2009).

In FA the contribution of each variable and to each factor was observed, being the factors defined by the differentiating attributes of the environments. As a tool for distinguishing environments and their different uses, six diagrams of the principal components (Factor 1 and 2, Factor 3 and 4, Factor 5 and 6) were performed for the physical-chemical attributes. From these data, two-dimensional diagrams were created to distinguish the areas and diagrams of vector projection to verify the soil attributes that distinguished most in the evaluated areas.

As described by Souza (2018), the association of soil physical and chemical attributes in different uses in agroecosystems evidences the correlation between the variables using the joint analysis with numerous factors and characteristics, being possible to explain the variability of the original set of variables, distinguishing environments through the most sensitive attributes. 
All statistical analysis were performed using the STATISTICA software version 7.0 (StatSoft, 2004).

\section{Results and Discussion}

Signifficant correlations of the variables were observed mainly for the attributtes AGRI (\%) $>2 \mathrm{~mm}$, DMP, DMG with T sand, Silt, $\mathrm{Ca}^{2+}, \mathrm{Mg}^{2+}, \mathrm{SB}, \mathrm{CEC}$, Macroporosity, Paeration. The DMG also presented correlation with clay. The total sand presented significant correlation with silt, clay, Ds, $\mathrm{P}, \mathrm{K}+\mathrm{Ca}^{2+}, \mathrm{Mg}^{2+}, \mathrm{SB}, \mathrm{CEC}$, Ptotal, Paeration and Ptcalc. The silt presented signficant correlation with $\mathrm{Ca}^{2+}, \mathrm{Mg}^{2+}, \mathrm{SB}, \mathrm{CEC}, \mathrm{V}, \mathrm{PST}$, Ptotal, Microp, Macro and Paeration. The sand presented this correlation with $\mathrm{Ds}, \mathrm{pH}, \mathrm{P}, \mathrm{K}^{+}$. The $\mathrm{Ca}^{2+}$ with $\mathrm{Mg}^{3+}, \mathrm{SB}, \mathrm{CEC}, \mathrm{v}, \mathrm{Microp}$. and Paeration (Table 1).

Table 1. Correlation of soil atributes variables of the evaluated areas at the Moacir Lucena Settlement, Rio Grande do Norte, Brazil

\begin{tabular}{|c|c|c|c|c|c|c|c|c|c|c|c|c|c|c|c|c|c|c|c|c|c|c|c|c|c|c|c|c|}
\hline & AGR $>2 \mathrm{~mm}$ & DMP & DMG & Areia T & Silt & Argila & Ds & Dp & $\mathrm{pH}$ & CE & COT & $\mathbf{P}$ & $\mathbf{K}^{+}$ & $\mathrm{Na}^{+}$ & $\mathrm{Ca}^{2+}$ & $\mathrm{Mg}^{2+}$ & SB & CTC & $\mathrm{V}$ & PST & Ptotal & Microp. & Macrop. & Paeracao & Ptcalc & LL & LP & IP \\
\hline AGR $>2 \mathrm{~mm}$ & 1.00 & & & & & & & & & & & & & & & & & & & & & & & & & & & \\
\hline DMP & 0.99 & 1.00 & & & & & & & & & & & & & & & & & & & & & & & & & & \\
\hline DMG & 0.87 & 0.86 & 1.00 & & & & & & & & & & & & & & & & & & & & & & & & & \\
\hline Areia $T$ & 0.58 & 0.59 & 0.71 & 1.00 & & & & & & & & & & & & & & & & & & & & & & & & \\
\hline Silt & -0.64 & -0.67 & -0.70 & -0.63 & 1.00 & & & & & & & & & & & & & & & & & & & & & & & \\
\hline Argila & -0.45 & -0.45 & -0.58 & -0.95 & 0.37 & 1.00 & & & & & & & & & & & & & & & & & & & & & & \\
\hline Ds & -0.06 & -0.05 & -0.33 & -0.68 & 0.12 & 0.77 & 1.00 & & & & & & & & & & & & & & & & & & & & & \\
\hline Dp & 0.12 & 0.16 & -0.07 & -0.26 & 0.43 & 0.14 & 0.19 & 1.00 & & & & & & & & & & & & & & & & & & & & \\
\hline $\mathrm{pH}$ & -0.18 & -0.19 & 0.09 & 0.35 & 0.36 & -0.56 & -0.84 & 0.15 & 1.00 & & & & & & & & & & & & & & & & & & & \\
\hline CE & -0.03 & -0.02 & 0.23 & 0.44 & -0.11 & -0.48 & -0.82 & -0.26 & 0.65 & 1.00 & & & & & & & & & & & & & & & & & & \\
\hline СOT & 0.09 & 0.12 & 0.37 & 0.34 & -0.55 & 0.20 & -0.34 & -0.15 & 0.08 & 0.44 & 1.00 & & & & & & & & & & & & & & & & & \\
\hline $\mathbf{P}$ & 0.10 & 0.05 & 0.35 & 0.57 & 0.09 & -0.72 & -0.76 & 0.11 & 0.79 & 0.40 & 0.26 & 1.00 & & & & & & & & & & & & & & & & \\
\hline $\mathbf{K}^{+}$ & 0.15 & 0.12 & 0.32 & 0.76 & -0.24 & -0.82 & -0.86 & -0.34 & 0.60 & 0.59 & 0.20 & 0.70 & 1.00 & & & & & & & & & & & & & & & \\
\hline $\mathrm{Na}^{+}$ & -0.28 & -0.27 & -0.12 & -0.12 & 0.22 & 0.06 & -0.47 & 0.08 & 0.48 & 0.77 & 0.29 & 0.10 & 0.19 & 1.00 & & & & & & & & & & & & & & \\
\hline $\mathrm{Ca}^{2+}$ & -0.56 & -0.55 & -0.58 & -0.49 & 0.81 & 0.27 & -0.17 & 0.55 & 0.50 & 0.24 & -0.19 & 0.17 & -0.07 & 0.64 & 1.00 & & & & & & & & & & & & & \\
\hline $\mathrm{Mg}^{2+}$ & -0.59 & -0.65 & -0.51 & -0.55 & 0.89 & 0.31 & -0.09 & 0.30 & 0.49 & 0.09 & -0.37 & 0.27 & -0.02 & 0.43 & 0.82 & 1.00 & & & & & & & & & & & & \\
\hline SB & -0.59 & -0.60 & -0.57 & -0.50 & 0.86 & 0.26 & -0.19 & 0.48 & 0.54 & 0.22 & -0.25 & 0.24 & -0.02 & 0.61 & 0.98 & 0.91 & 1.00 & & & & & & & & & & & \\
\hline CTC & -0.64 & -0.66 & -0.61 & -0.53 & 0.86 & 0.30 & -0.16 & 0.43 & 0.50 & 0.19 & -0.24 & 0.22 & -0.01 & 0.59 & 0.97 & 0.92 & 0.99 & 1.00 & & & & & & & & & & \\
\hline $\mathrm{v}$ & -0.32 & -0.33 & -0.20 & -0.13 & 0.72 & -0.12 & -0.43 & 0.41 & 0.80 & 0.39 & -0.22 & 0.47 & 0.07 & 0.45 & 0.73 & 0.69 & 0.75 & 0.69 & 1.00 & & & & & & & & & \\
\hline PST & 0.43 & 0.47 & 0.44 & 0.26 & -0.66 & -0.06 & -0.13 & -0.21 & -0.24 & 0.44 & 0.47 & -0.31 & 0.05 & 0.46 & -0.25 & -0.52 & -0.35 & -0.37 & -0.37 & 1.00 & & & & & & & & \\
\hline Ptotal & -0.42 & 0.44 & -0.55 & -0.72 & 0.68 & 0.60 & 0.41 & 0.24 & -0.06 & -0.14 & -0.35 & -0.32 & -0.63 & 0.15 & 0.44 & 0.46 & 0.44 & 0.42 & 049 & -0.28 & 1.00 & & & & & & & \\
\hline Microp. & -0.49 & -0.52 & -0.43 & -0.48 & 0.75 & 0.28 & 0.07 & 0.30 & 0.38 & -0.13 & -0.42 & 0.16 & -0.27 & 0.12 & 0.58 & 0.74 & 0.65 & 0.64 & 0.62 & -0.58 & 0.46 & 1.00 & & & & & & \\
\hline Macrop. & 0.57 & 0.61 & 0.36 & 0.36 & -0.63 & -0.19 & 0.08 & -0.07 & -0.45 & -0.07 & 0.14 & -0.30 & 0.12 & -0.22 & -0.50 & -0.71 & -0.58 & -0.59 & -0.57 & 0.49 & -0.39 & -0.92 & 1.00 & & & & & \\
\hline Paeracao & -0.58 & -0.57 & -0.84 & -0.59 & 0.69 & 0.44 & 0.20 & 0.27 & 0.03 & -0.12 & -0.47 & -0.28 & -0.32 & 0.17 & 0.64 & 0.46 & 0.60 & 0.61 & 0.40 & -0.34 & 0.65 & 0.49 & -0.32 & 1.00 & & & & \\
\hline Ptcalc & -0.20 & -0.19 & -0.50 & -0.73 & 0.41 & 0.72 & 0.79 & 0.45 & -0.52 & -0.80 & -0.42 & -0.50 & -0.80 & -0.44 & 0.16 & 0.15 & 0.13 & 0.14 & -0.02 & -0.44 & 0.57 & 0.25 & -0.02 & 0.51 & 1.00 & & & \\
\hline LL & -0.26 & -0.25 & 0.03 & 0.18 & 0.13 & -0.27 & -0.64 & -0.28 & 0.63 & 0.91 & 0.24 & 0.25 & 0.36 & 0.76 & 0.34 & 0.26 & 0.34 & 0.31 & 0.51 & 0.28 & 0.10 & 0.16 & -0.34 & 0.02 & -0.67 & 1.00 & & \\
\hline LP & 0.66 & 0.73 & 0.36 & 0.24 & -0.48 & -0.10 & 0.18 & 0.36 & -0.36 & -0.09 & 0.05 & -0.36 & -0.20 & -0.09 & -0.25 & -0.65 & -0.40 & -0.45 & -0.29 & 0.57 & -0.12 & -0.47 & 0.66 & -0.03 & 0.12 & -0.27 & 1.00 & \\
\hline IP & -0.21 & -0.19 & 0.08 & 0.23 & 0.07 & -0.31 & -0.64 & -0.29 & 0.61 & 0.92 & 0.27 & 0.24 & 0.37 & 0.75 & 0.29 & 0.20 & 0.29 & 0.26 & 0.48 & 0.32 & 0.06 & 0.12 & -0.30 & -0.02 & -0.70 & 1.00 & -0.22 & 1.00 \\
\hline
\end{tabular}

Note. AGRI (\%) > 2 mm: aggregates above $2 \mathrm{~mm}$; DMP: average weighted diameter; DMG: geometric mean diameter; Areia T: total sand; Silt; Clay; Ds: soil density; Dp: particle density; pH: hidrogenionic potential; CE: eletric condutivity; TOC: total organic carbon; $\mathrm{P}$ : phosphorus; $\mathrm{K}^{+}$: potassium; $\mathrm{Na}^{+}$: sodium; $\mathrm{Ca}^{2+}$ : clcium; $\mathrm{Mg}^{2+}$ : magnesium; CEC: cation exchange capacity; V: base saturation; PST: sodium exchenge percentage; LL: liquidity limit; LP: plasticity limit; IP: plasticity index; Ptdet.: total posity; Ptcal: calculated total porosity; Microp: microporosity; Macrop: macroporosity.

After the standardization of the data by the correlation matrix, the cluster analysis was performed, represented by the dendrogram (Figure 1), with significant variation in the Euclidean distance values between the areas for considered variables. With the analysis of grouping of the analytical results, four groups were formed for the soil classes and for the attributes of the studied soils, showing greater similarity between them.

From the selected attributes, a first classification of the areas was performed according to the similarity between the studied environments. The first group (G1) was defined with reference to the surface horizon of each profile (1AR.A, 2AL.A, and 3CAJU.Ap), which indicates that the soil intrinsic characteristics was a determinant factor. This can be justified as a function of soil texture, where the sand variable presented higher concentration in G1, presented in considerable amounts on the surface of the three evaluated environments (Figure 1A). The 3CAJU (Latosol) presented greater dissimilarity in G1 when compared to 1AR.A and 2AL.A, with a greater percentage of the sand fraction $\left(813 \mathrm{~g} \mathrm{~cm}^{-3}\right)$ when compared to other areas. The physical attributes were: AGRI $(\%)>2 \mathrm{~mm}$, DMP, DMG, PST, Macrop and LP, being in agreement with the correlation values between the variables presented in the matrix (Table 1) and in the dendrogram (Figure 2A).

The G2 was differentiated by the dendrogram, correlating the areas: 1AR and 3CAJU (1AR.AB; 3CAJU.BC and 3CAJU.BA); the individuality of these areas are related to the soil class (Latosol), evidencing that the $2 \mathrm{AL}$ (Cambissol) presented different characteristics regarding the evaluated attributes. 
In G3 all the horizons observed in the studied environments (1AR.Bi, 3CAJU.Bi and 2 AL.Bi) were highlighted, as well as the transition horizons in P1 and P2 (1AR.BA, 1AR.BC, 2AL.BA). In the groups characterization, G3 presented greater similarity between them, except for 2AL.BC (Cambisol), which presented greater dissimilarity in relation to others, which indicates that this environment present differentiated particularities according to the analyzed variables. This can be justified by the higher content of clay, and of microp., Ptotal, Paeration, which means, the inherent fractions of the material and origin and the physical and structural attributes were determinant in the dissimilarity for the Cambisols, identifying critical conditions for radicular growth restriction due to mechanical obstruction or aeration deficiency.

The dendrograms analysis (Figures 1A and 1B) lead to the formation of distinct clusters for soil attributes, which grouped variables that are related in determining the soil characteristic, where four groups of variables were observed and the lowest dissimilarity was presented between DMP and AGRO $>2 \mathrm{~mm}, \mathrm{SB}$ and $\mathrm{Ca}^{2+}, \mathrm{and}^{2+}$ and silt. The formation of clusters with different soil classes was observed, with variables of the respective classes with similar characteristics being grouped, with three groups standing out. The lowest dissimilarity was observed in the transition horizons in the Latosol Class (1AR.AB and 3CAJU.BC).

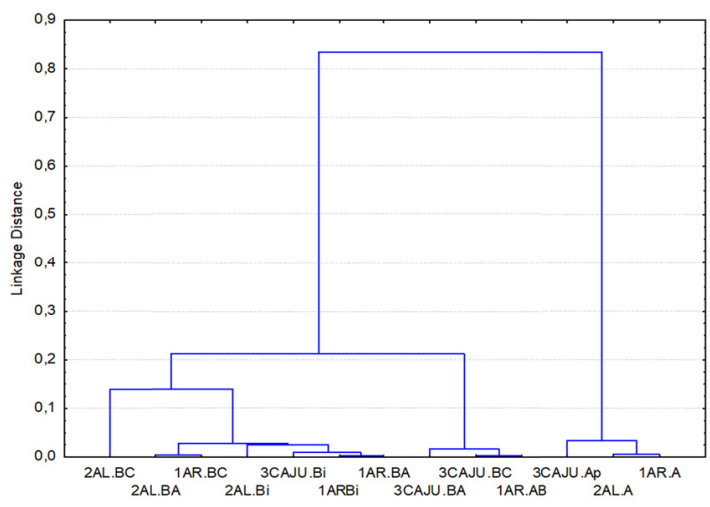

A

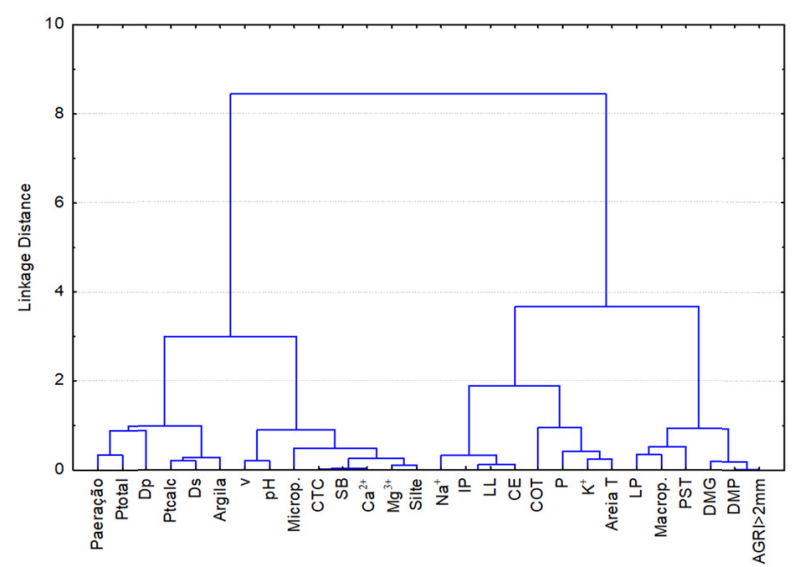

B

Figure 1. Dendograms of the hierarquical group analysis resulted from the hieralquical analysis of grouping, evidencing the groups

Source: The authors.

The highest potassium losses in the soil were in the Test 1 from the 27 variables, six factors (F1 to F6) were extracted, where the cumulative proportion explained $93 \%$ of the total variability of the results, showing the influence of soil attributes on the environments differentiation, where factor loads indicate the intensity that a factor explains each variable. Thus, Table 2 shows the distribution of the factor loads, with the respective eigenvalues, the percentage of explanation of the total and accumulated variance values. $\mathrm{Dp}, \mathrm{Ca}^{2+}, \mathrm{SB}, \mathrm{CTC}$, Total Sand, Clay and Ds.

With the F1, it was possible to estimate the influence of the variables $\mathrm{Dp}, \mathrm{Ca}^{2+}, \mathrm{Mg}^{2+}, \mathrm{SB}$ and $\mathrm{CEC}$ for the environments differentiation. For F2, the variables that stood out were: Total Sand, Clay, pH, P, K, F1 and F2 that, togheter, presented a cumulative variance of $65.89 \%$, which means higher separations of the environments. The variables that stood out in Factor 3 were (F3): CE, Na ${ }^{+}$, LL and IP. The Factor 4 (F4) included the variables that describe the soil aggregates: DMP, DMG, AGRI (\%) $>2 \mathrm{~mm}$ and LP. The variables Microp., Macrop. and TOC represent the least expressive factors (F5 and F6), however, influenced by the attributes selected in F1 and F2, with a decrease in the number of soil attributes and total variance of the data (Table 1). 
Table 2. Factorial axes for the soil atributes and their respective factorial weights, eigenvalues, total and accumulated variance

\begin{tabular}{|c|c|c|c|c|c|c|}
\hline & Factor 1 & Factor 2 & Factor 3 & Factor 4 & Factor 5 & Factor 6 \\
\hline AGRI $>2 \mathrm{~mm}$ & -0.22 & -0.18 & -0.13 & -0.87 & -0.26 & -0.07 \\
\hline DMP & -0.21 & -0.16 & -0.11 & -0.89 & -0.32 & -0.07 \\
\hline DMG & -0.31 & -0.34 & 0.09 & -0.79 & 0.00 & -0.35 \\
\hline T Sand & -0.35 & -0.79 & 0.14 & -0.41 & -0.19 & -0.08 \\
\hline Silt & 0.64 & 0.15 & -0.04 & 0.39 & 0.46 & 0.41 \\
\hline Clay & 0.17 & 0.89 & -0.15 & 0.34 & 0.05 & -0.07 \\
\hline Ds & -0.13 & 0.82 & -0.51 & 0.01 & -0.02 & 0.08 \\
\hline $\mathrm{Dp}$ & 0.82 & 0.14 & -0.31 & -0.39 & 0.01 & 0.04 \\
\hline $\mathrm{pH}$ & 0.43 & -0.66 & 0.42 & 0.00 & 0.39 & 0.08 \\
\hline $\mathrm{CE}$ & 0.10 & -0.42 & 0.88 & 0.00 & -0.07 & -0.12 \\
\hline TOC & -0.11 & -0.13 & 0.29 & -0.06 & -0.16 & -0.78 \\
\hline $\mathrm{P}$ & 0.25 & -0.83 & 0.02 & -0.11 & 0.39 & -0.18 \\
\hline $\mathrm{K}_{+}$ & -0.08 & -0.93 & 0.22 & 0.11 & -0.13 & -0.07 \\
\hline $\mathrm{Na}_{+}$ & 0.51 & 0.02 & 0.80 & 0.15 & -0.09 & -0.22 \\
\hline $\mathrm{Ca}^{2+}$ & 0.89 & 0.06 & 0.23 & 0.32 & 0.15 & 0.12 \\
\hline $\mathrm{Mg}^{2+}$ & 0.65 & 0.02 & 0.07 & 0.41 & 0.53 & 0.10 \\
\hline SB & 0.85 & 0.01 & 0.20 & 0.37 & 0.28 & 0.12 \\
\hline CEC & 0.82 & 0.02 & 0.16 & 0.45 & 0.27 & 0.08 \\
\hline V & 0.63 & -0.18 & 0.36 & -0.03 & 0.50 & 0.34 \\
\hline PST & -0.17 & 0.18 & 0.54 & -0.34 & -0.58 & -0.35 \\
\hline Ptotal & 0.29 & 0.62 & 0.14 & 0.13 & 0.31 & 0.45 \\
\hline Microp. & 0.39 & 0.16 & 0.01 & 0.17 & 0.77 & 0.25 \\
\hline Macrop. & -0.25 & -0.07 & -0.17 & -0.29 & -0.84 & -0.02 \\
\hline Paeração & 0.46 & 0.31 & 0.02 & 0.44 & -0.06 & 0.61 \\
\hline Ptcalc & 0.23 & 0.64 & -0.62 & 0.07 & 0.03 & 0.27 \\
\hline LL & 0.07 & -0.20 & 0.94 & 0.11 & 0.19 & 0.02 \\
\hline LP & 0.04 & 0.19 & -0.03 & -0.66 & -0.66 & 0.15 \\
\hline IP & 0.04 & -0.21 & 0.95 & 0.07 & 0.16 & 0.01 \\
\hline Eigenvalues & 10.65 & 7.80 & 2.92 & 2.41 & 1.26 & 1.14 \\
\hline Total variance $(\%)$ & 38.04 & 27.85 & 10.41 & 8.61 & 4.49 & 4.06 \\
\hline $\begin{array}{l}\text { Accumulated Variance } \\
(\%)\end{array}$ & 38.04 & 65.90 & 76.31 & 84.92 & 89.41 & 93.47 \\
\hline
\end{tabular}

Note. GRI (\%) > 2 mm: aggregates above $2 \mathrm{~mm}$; DMP: average weighted diameter; DMG: geometric mean diameter; Areia T: total sand; Silt; Clay; Ds: soil density; Dp: particle density; $\mathrm{pH}$ : hidrogenionic potential; CE: eletric condutivity; TOC: total organic carbon; P: phosphorus; $\mathrm{K}^{+}$: potassium; $\mathrm{Na}^{+}$: sodium; $\mathrm{Ca}^{2+}$ : clcium; $\mathrm{Mg}^{2+}$ : magnesium; CEC: cation exchange capacity; V: base saturation; PST: sodium exchenge percentage; LL: liquidity limit; LP: plasticity limit; IP: plasticity index; Ptdet.: total posity; Ptcal: calculated total porosity; Microp.: microporosity; Macrop.: macroporosity.

Source: The authors.

The factors F1 and F2 explained $65.89 \%$ of the total variation of the attributes (physical, chemical and structural), being the variables that most characterize the studied soil classes (Table 2). F1 explained $38.04 \%$ of the total variation, and the highest correlation coefficients $(\geq|0.65|)$ were identified for the variables $\mathrm{Dp}, \mathrm{Ca}^{2+}, \mathrm{Mg}^{2+}, \mathrm{SB}$ and CEC, according to Figure 2. The variable Dp, which refers to solids (soil matrix), was highlighted by the fact that the soils under study are considered as minerals, ranging from 2.51 to 3.04 g.cm-3, associated with chemical and structural characteristics (F1 to F6). For the chemical attributes $\mathrm{Ca}^{2+}, \mathrm{Mg}^{2+}, \mathrm{SB}$ and $\mathrm{CEC}$, the representativeness in F1 was for the Cambisol (P2) as a function of the mineralogical characteristics of the clays from the source material of the Jandaíra limestone (Dnocs, 1978). According to Ronquim et al., (2010), the CEC of these soils is occupied by essential cations such as $\mathrm{Ca}^{2+}, \mathrm{Mg}^{2+}$ with predominantly high activity of clay, ilite 
(2:1), mica (2:1) and vermiculite (2:1), attributing natural fertility, with the exception of the Latosols (P1 and P2) that were not close (Figure 2), because it is formed by sediments belonging to the Barreiras Group.

In F2, the explained variance was $27.85 \%$, involving soil intrinsic attributes, chemical and structural: $\mathrm{T}$ Sand, Clay, Ds, $\mathrm{pH}, \mathrm{P}, \mathrm{K}^{+}$, evidencing the interrelationships between them. Thus, the soil structure refers to the organized arrangement of the solid phase, mainy the porous space (macropores and micropores), and consequently its structure, ehich is dynamic and functional (Ferreira et al., 2010). The results were presented as a function of the granulometric fraction of the soil (clay, silt and sand) that are inherent to the material of origin (lithology) associated to the factors and processes of soil formation.

Inorganic fractions were differentiated between classes, and the sand fraction was discriminant for the Yellow Red Latosol and Eutrophic Yellow Latosol, belonging to the Barrreiras Group, while the eutrophic character is due to the climatic pattern of the semiarid region of the Northeast of Brazil, reducing chemical weathering and leaching of exchangeable bases. PST was a determinant variable for the Eutrophic Red Latosol (3CAJU) class, in accordance with the clustering analysis (Figure 1). It is important to notice that it is a particularrity of the region due to the scarcity of rainfall, with chemical weathering and reduced leaching of the exchangeable bases. Ker (1997) indicate that there is spatial and temporal variability of the soil attributes for the Latosol class, where the climatic pattern strongly influences the chemical weathering, corroborating with the research results, presenting favorable physical conditions for soil water drainage. However, the local particularity was a limiting agent in bases leaching $\left(\mathrm{Ca}^{2+}, \mathrm{Mg}^{2+}, \mathrm{Na}^{+}\right.$and $\left.\mathrm{K}^{+}\right)$.

The silt and clay fractions differentiated the Haplic Cambisol (2AL) belonging to the Jandaíra limestone formation, being recent, not weathered soils, with good chemical characteristics and physical limitations, as for the porous space, due to the location of the soil at the lowest level (colluvium), with a reflection on the poor drainage and the contribution of sediments from the highest levels, with predominance of exchangeable bases and high CEC, according to Figure 2.

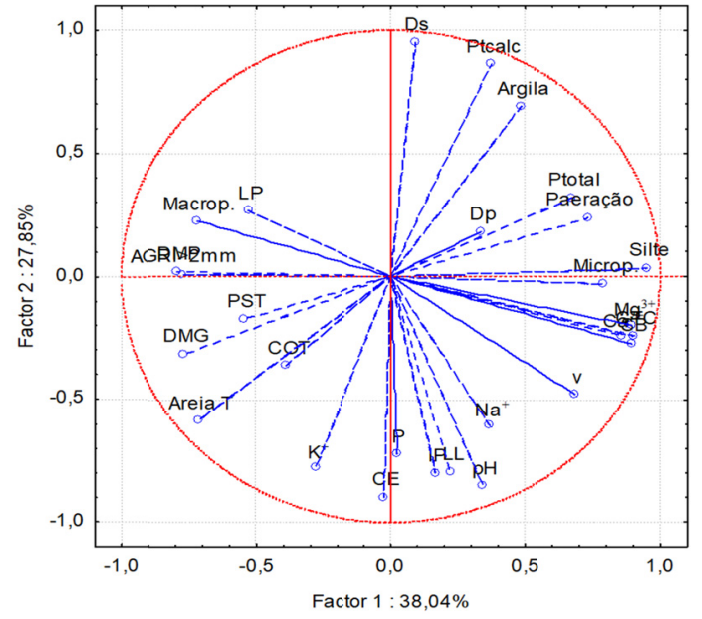

A

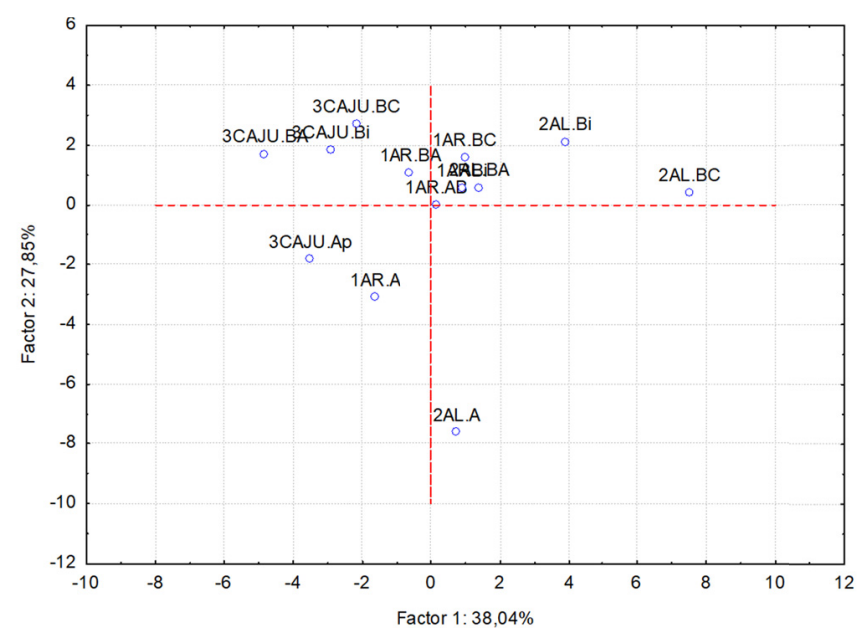

B

Figure 2. Vector projection diagram (A), and ordering diagram of the main components for the studied areas (B) for factors 1 and 2

The variables with the highest weight for factor 3 were: $\mathrm{LL}, \mathrm{IP}, \mathrm{CE}$ and $\mathrm{Ca}^{2+}$ and for factor 4 the AGRI $>2 \mathrm{~mm}$, DMP and DMG. These results demonstrate the relation between the physical and chemical attributes associated with the structural attributes.

The F3, generated for the soil attributes explained $10.41 \%$ of the total variation of the studied attributes, the variables that stood out were: $\mathrm{CE}, \mathrm{Na}^{+}, \mathrm{LL}$ and IP. In the Factor 4 (F4) were variables that describe the soil aggregates: DMP, DMG and AGRI (\%) $>2 \mathrm{~mm}$ and LP, explaining $8.61 \%$ of the data.

According to the analysis of the aggregates, the 3CAJU—cashew tree área, that refers to a periodically managed área-resulted in a smaller percentage of aggregates above $2 \mathrm{~mm}$ and lower DMP, meaning a smaller structure than the other areas due to the management. The arrangement of the pores and aggregates, delineated by the soil structure, influenced the processes involved in the formation, stability and aggregation. Inadequate management 
directly influences the structural aspects of the soil, especially in the superficial horizons. The DMG values were similar when compared to other environments.

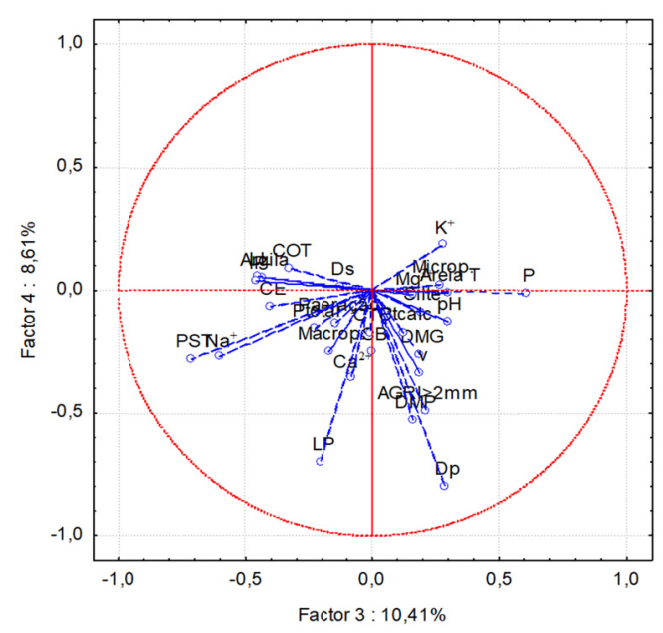

A

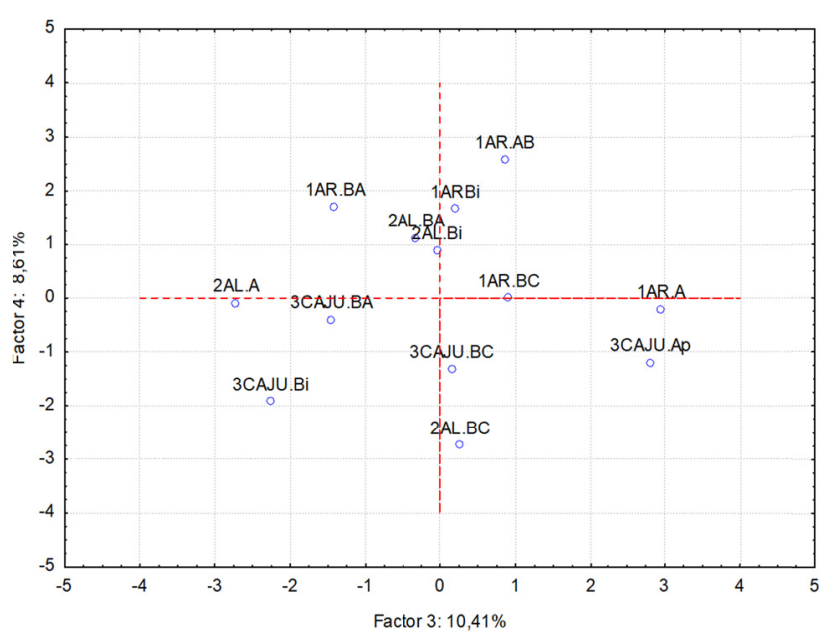

B

Figure 3. Vector projection diagram (A) and ordering diagram of the main components for the studied areas (B) for factors 3 and 4

The variables Microp., Macrop., and TOC represent the factors F5 and F6 with variation of $4.49 \%$ and $4.06 \%$, respectivelly. The higher porosity was observed for Latossol (3CAJU). According to Goés et al. (2018) in a structurate soil, higher values of macroporosity were observed, resulting in larger spaces, favoring soil drainage and aeration, without physic restrictions for the root growth and development.

Lower DMW values were observed in the 2AL (Latosol) horizon, as a function of the predominance of the sand fraction, to the detriment of clay, presenting lower cohesion strength. The DMP in the 3CAJU (Latossol) horizon differed from the others, varying from 2.35 to $2.53 \mathrm{~mm}$, which is associated to the increment of the clay fraction type 1:1 and $\mathrm{Fe}$ and $\mathrm{Al}$ oxides, as well as the increase of TOC, explaining the aggregation process with consequently greater aggregates stability.

In the 1AR (Latosol) horizon, a high aggregation value was observed in the surface, decreasing along the profile, which can be explained by the microbial activity on the vegetal residues present in the soil surface, where higher contents of organic matter are present.

Structured soils usually favor root development, as the natural path of root growth in the soil is favored by macropores, or in spaces between aggregates, which in non-compacted soils are interconnected (Tavares, 2018).

The F5 is represented by microporosity, macroporosity, LP and F6 by TOC. Analyzing the Figures (4A and B), the TOC was the attribute that discriminated most the area 1AR.BA (Latosol), with values lower than those observed in the Cambisol class on the surface. Marinho et al. (2016) observed similar results, with representative TOC for a semiarid condition in the Haplic Cambisol class.

One of the attributes that is correlated with the structural aspects of the soil is the aggregation, and since it has soils with high clay content, the clay particles act as a aggregating agent, providing greater stability of the aggregates.

According to Brito et al. (2017) the Haplic Cambissol is the most frequent in areas with limestone, with intermediate weathering, with not advanced physical and chemical transformations. 


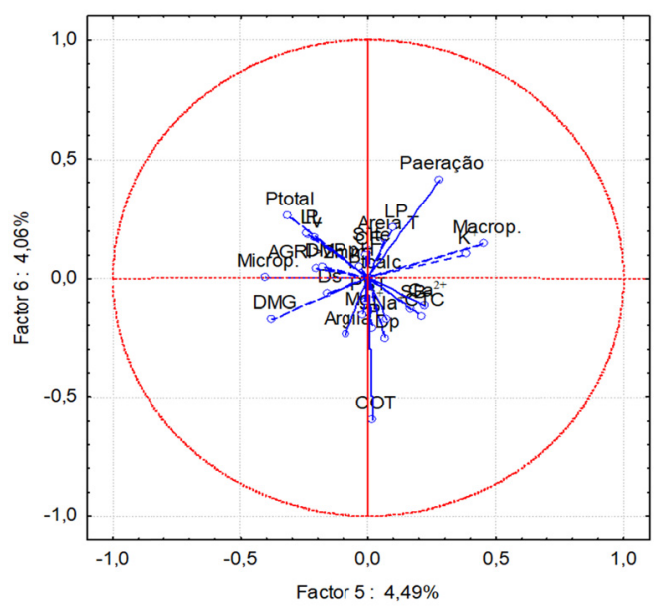

A

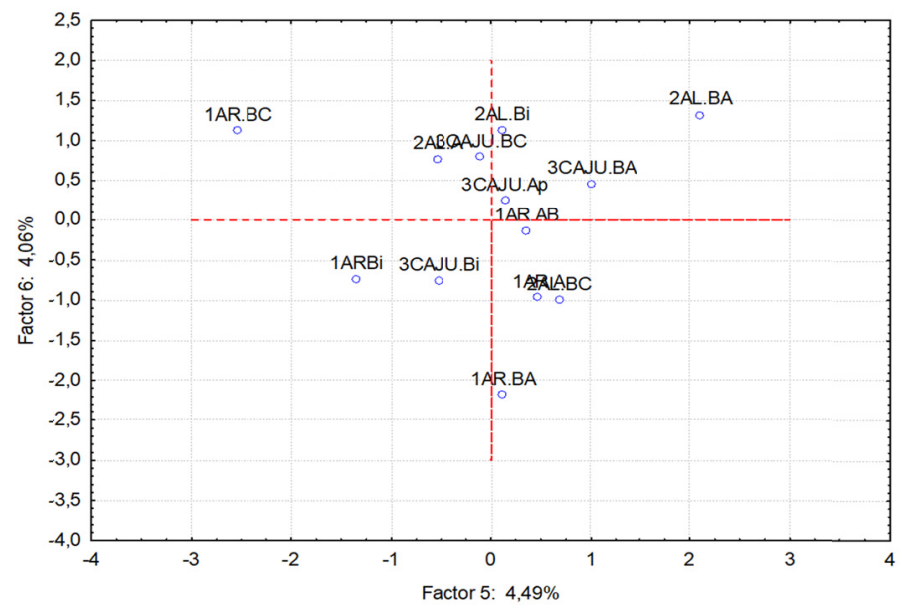

B

Figure 4. Vector projection diagram (A) and ordering diagram of the main components for the studied areas (B) for factors 5 and 6

\section{Conclusions}

The physical, chemical and structural attributes were indicators in the differentiation of soil classes and uses, however, the most sensitive were particle density (Dp), $\mathrm{Ca}^{2+}, \mathrm{Mg}^{2+}$, sum of bases (SB), cation exchange capacity (CEC), total sand, clay, soil density (Ds), $\mathrm{pH}, \mathrm{P}$ and $\mathrm{K}^{+}$.

The principal component analyses showed Ds, Silte e CE indicators of environments separation.

The cluster analysis identified for the Haplic Cambisol the clay fraction and the structural attributes (microporosity, total porosity and aeration porosity) with greater dissimilarity, identifying critical conditions for restrictions to root growth due to mechanical impediment or aeration deficiency.

The percentage of exchangeable sodium (PST) was a determinant variable for the Eutrophic Red Latosol (3CAJU) class, in agreement with the cluster analysis and factorial analysis with the extraction of the principal components.

\section{Acknowledgements}

To the Coordination of Improvement of Higher Level Personnel (CAPES), for the financial support in order to carry out the research, and to the Soil and Water Management Graduate Program (PPGMSA) of the Semiarid Rural Federal University (UFERSA), for providing the facilities used for this paper.

\section{References}

Alvares, C. A., Stape, J. L., Sentelhas, P. C., de Moraes, G., Leonardo, J., \& Sparovek, G. (2013). Köppen's climate classification map for Brazil. Meteorologische Zeitschrift, 711-728. https://doi.org/10.1127/ 0941-2948/2013/0507

Angelim, L. A. A., Angelim, V. C., \& Nesi, J. R. (2006). Programa Geologia do Brasil-PLGB. Projeto Geologia e Recursos Minerais do Estado do Rio Grande do Norte. Mapa Geológico do Estado do Rio Grande do Norte. Escala, Recife: CPRM/FAPERN.

Brady, N. C., \& Weil, R. R. (2013). Elementos da natureza e propriedades dos solos. Bookman Editora.

Carvalho, A. E. M., Lima, L. A., de Sousa Oliveira, L., \& Costa, M. C. G. (2017). Diagnóstico do uso e conservação do solo em região de reforma agrária no semiárido. Revista Verde de Agroecologia e Desenvolvimento Sustentável, 568-573. https://doi.org/10.18378/rvads.v12i3.4870

Castilho, K. B., Cortez, J. W., Olszevski, N., Salviano, A. M., \& Trindade, M. H. (2017). Análise multivariada da qualidade química de um Latossolo sob sistemas de manejo do solo. Agrarian, 10(36). 162-169. https://doi.org/10.30612/agrarian.v10i36.4179

Forsythe, W. (1975). Manual de laboratorio: Física de suelos (No. IICA-LME 25). IICA, San José (Costa Rica). 
Hair, J. F., Black, W. C., Babin, B. J., Anderson, R. E., \& Tatham, R. L. (2009). Análise multivariada de dados. Bookman Editora.

Ghidin, A. A., Melo, V. D. F., Costa Lima, V., \& Jonasson Costa Lima, J. M. (2006) Toposseqüências de latossolos originados de rochas basálticas no Paraná. I-Mineralogia da fração argila. Revista Brasileira de Ciência do Solo, 30(2). https://doi.org/10.1590/S0100-06832006000200011

Ribeiro, B. T., Magalhães, C. A. S., Lima, J. M., \& Silva, M. L. N. (2007). Calibração e uso de minissimulador de chuva para estudos de erosão e poluição do solo (Boletim Técnico, No. 17, pp. 1-17). Lavras: UFLA.

Kemper, W. D., \& Rosenau, R. C. (1986). Aggregate stability and size distribution.

Ker, J. C. (1997). Latossolos do Brasil: Uma Revisão. Geonomos, 5, 17-40. https://doi.org/10.18285/geonomos. v5i1.187

Kiehl, E. J. (1979). Manual de edafologia: Relações solo-planta (p. 262). São Paulo: Ceres.

Leite, J. N. F., Cruz, M. C. P. D., Ferreira, M. E., Andrioli, I., \& Braos, L. B. (2016). Organic and inorganic P forms in soil as affected by cover crops and nitrogen fertilization. Pesquisa Agropecuária Brasileira, 51(11), 1880-1889. https://doi.org/10.1590/s0100-204x2016001100010

Lepsch, I. F., Espindola, C. R., Vischi Filho, O. J., \& Hernani, L. C. (2015). Manual para levantamento utilitário e classificação de terras no sistema de capacidade de uso. Campinas: SBCS.

Machado Vezzani, F., \& Mielniczuk, J. (2009). Uma visão sobre qualidade do solo. Revista Brasileira de Ciência do Solo, 33(4). https://doi.org/10.1590/S0100-06832009000400001

Machado, V. J., \& de Souza, C. H. E. (2012). Disponibilidade de fósforo em solos com diferentes texturas após aplicação de doses crescentes de fosfato monoamônico de liberação lenta. Bioscience Journal, 28(1).

Marinho, A. C. C. S., Portela, J. C., Silva, E. F., Dias, N. S., Sousa Júnior, F. S., Silva, A. C., \& Silva, J. F. (2016). Organic matter and physicochemical attributes of a Cambisol under different agricultural uses in a semi-arid region of Brazil. Australian Journal of Crop Science, 10, 32-41.

Mota, A. J. C., Nonato de Assis Júnior, R., Amaro Filho, J., \& Libardi, P. L. (2008). Algumas propriedades físicas e hídricas de três solos na chapada do Apodi, RN, cultivados com melão. Revista Brasileira de Ciência do Solo, 32(1). https://doi.org/10.1590/S0100-06832008000100006

Pereira, M. G., Loss, A., Beutler, S. J., \& Torres, J. L. R. (2011). Carbono, matéria orgânica leve e fósforo remanescente em diferentes sistemas de manejo do solo. Pesquisa Agropecuária Brasileira, 45(5), 508-514. https://doi.org/10.1590/S0100-204X2010000500010

Perin, A., Silva Santos, R. H., Urquiaga Caballero, S. S., Marinho Guerra, J. G., \& Gusmão, L. A. (2010). Acúmulo e liberação de $\mathrm{P}, \mathrm{K}, \mathrm{Ca}$ e $\mathrm{Mg}$ em crotalária e milheto solteiros e consorciados. Revista Ceres, 57(2). https://doi.org/10.1590/S0034-737X2010000200020

Ribeiro, A. C., \& Guimarães, P. T. G. (1999). Recomendações para o uso de corretivos e fertilizantes em Minas Gerais ( $5^{\text {a }}$ aproximação). Comissão de Fertilidade do Solo do Estado de Minas Gerais.

Ribeiro, K. D., Menezes, S. M., de Freitas, M. D. G. B., \& Sampaio, F. D. M. T. (2007). Propriedades físicas do solo, influenciadas pela distribuição de poros, de seis classes de solos da região de Lavras-MG. Ciência e Agrotecnologia, 31(4), 1167-1175. https://doi.org/10.1590/S1413-70542007000400033

Sá Paye, H., Vargas de Mello, J. W., \& Bezerra de Melo, S. (2012). Métodos de análise multivariada no estabelecimento de valores de referência de qualidade para elementos-traço em solos. Revista Brasileira de Ciência do Solo, 36(3). https://doi.org/10.1590/S0100-06832012000300033

Souza, H. S., Tsukamoto Filho, A. D. A., de Souza, É. C., Arriel, D. A. A., \& Medeiros, R. A. (2018). Análise multivariada de atributos químicos e físicos do solo em sistema agroflorestal com teca. Scientia Agraria, 19(1), 87-93. https://doi.org/10.5380/rsa.v19i1.53385

StatSoft. (2004). Statistica Version 7.0. Retrieved from http://www.statsoft.com

Teixeira, P. C., Donagemma G. K., Wenceslau, A. F., \& Teixeira, G. (2017). Manual de Métodos de Análise de Solo (3rd ed., p. 573). Rio de Janeiro: Embrapa Solos.

Turrión, M. B., López, O., Lafuente, F., Mulas, R., Ruipérez, C., \& Puyo, A. (2007). Soil phosphorus forms as quality indicators of soils under different vegetation covers. Science of the Total Environment, 378(1-2), 195-198. https://doi.org/10.1016/j.scitotenv.2007.01.037 
Vasconcelos, R. D., Cantalice, J. R. B., Silva, A. J. N. D., Oliveira, V. D., \& Silva, Y. J. A. B. (2010). Limites de consistência e propriedades químicas de um Latossolo amarelo distrocoeso sob aplicação de diferentes resíduos da cana-de-açúcar. Revista Brasileira de Ciência do Solo, 34(3), 639-648. https://doi.org/10.1590/ S0100-06832010000300005

\section{Copyrights}

Copyright for this article is retained by the author(s), with first publication rights granted to the journal.

This is an open-access article distributed under the terms and conditions of the Creative Commons Attribution license (http://creativecommons.org/licenses/by/4.0/). 